Arq. Bras. Med. Vet. Zootec., v.62, n.2, p.481-483, 2010

\title{
Communication
}

[Comunicação]

\section{Equine intestinal pythiosis in Southern Brazil}

\author{
[Pitiose intestinal em equino no Sul do Brasil] \\ P.S. Bezerra Júnior ${ }^{1}$, P.M.O. Pedroso ${ }^{1}$, S.P. Pavarini ${ }^{1}$, A.G.C. Dalto ${ }^{1}$, \\ J.M. Santurio ${ }^{2}$, D. Driemeier ${ }^{1 *}$ \\ ${ }^{1}$ Faculdade de Veterinária - UFRGS \\ 91540-000 - Porto Alegre, RS \\ ${ }^{2}$ Universidade Federal de Santa Maria - Santa Maria, RS
}

Pythiosis is a worldwide disease caused by the Oomycete Pythium insidiosum (Santurio et al., 2006). Although horses are most commonly affected, the disease has also been described in dogs (Dykstra et al., 1999), cats (Barker et al., 1993), cattle (Santurio et al., 1998), sheep (Tabosa et al., 2004), and humans (Bosco et al., 2005).

The most common clinical presentation of the disease is the cutaneous form, which is characterized by granulomatous ulcerative lesions and yellow to tan necrotic masses, also termed 'kunkers' (Santurio et al., 2006). Nevertheless, isolated cases of enteric pythiosis have sporadically been described in horses (Brown and Roberts, 1988; Morton et al., 1991; Purcell et al., 1994), cats (Barker et al., 1993), and most commonly in dogs (Dykstra et al., 1999). The pathogenesis of intestinal pythiosis is not completely understood. It has been suggested that previous injury caused by vegetal material or pathogenic agents on the intestinal mucosa may be important predisposing factors (Morton et al., 1991; Purcell et al., 1994). Alternatively, the disease could also occur by active penetration of the agent (Brown and Roberts, 1988). This case report describes the pathologic and immunohistochemical findings observed in a case of equine intestinal pythiosis.

An eight-year-old English Thoroughbred mare was presented for clinical examination with a

Recebido em 22 de outubro de 2009

Aceito em 31 de março de 2010

*Autor para correspondência (corresponding author)

Email: davetpat@ufrgs.br history of recurrent episodes of colic. Exploratory laparotomy revealed an approximately $10 \mathrm{~cm}$ long, markedly thickened jejunal segment affected by extensive ulceration associated with white to yellow necrotic and pale fibrotic areas (Figure 1). The affected jejunal segment was excised due to a partial luminal obstruction, fixed in $10 \%$ formalin, and submitted for histologic processing. Representative samples were routinelly processed for histopathology, paraffinembedded, sectioned at $5 \mu \mathrm{m}$, and stained with hematoxylin \& eosin (HE) and Grocott's Methenamine Silver stains (GMS). Selected sections of jejunal lesions were immunostained with a rabbit polyclonal antibody against Pythium insidiosum by using a labeled streptavidin-biotin peroxidase technique as previously described (Pedroso et al., 2009). The antibody was produced by the Laboratório de Pesquisas Micológicas at the Universidade Federal de Santa Maria (LAPEMI-UFSM) and the procedure was approved by the Animal Welfare Committee at the Universidade Federal de Santa Maria (Pereira et al., 2007). Positive and negative controls consisted of tissues infected by culture-confirmed Pythium insidiosum and Conidiobolus spp., respectively.

Microscopically, the affected jejunal segment was composed of multifocal to coalescening, transmural, pyogranulomatous enteritis containing numerous necrotic foci and hyphaelike structures (Figure 2), which appeared as negative images at $\mathrm{HE}$, but stained positively 
with GMS stain. Hyphae were rarely sepated, irregularly branched, with wide non-parallel walls, surrounded by numerous eosinophils, fewer neutrophils and macrophages, and abundant fibrous connective tissue. The walls of the hyphaelike structures stained positively for antibodies against $P$. insidiosum (Figure 3 ) in affected samples and positive controls, whereas, negative controls samples were not stained for $P$. insidiosum.

A diagnosis of intestinal pythiosis was made based on the gross, microscopic, and immunohistochemical findings. Since the affected intestinal segment was submitted for diagnosis fixed in formalin, culture and isolation of the agent could not be performed. In such cases, immunohistochemistry may confirm the diagnosis (Brown et al., 1988). Cases of enteric pythiosis in horses have previously been associated with clinical signs of colic (Brown and Roberts, 1988; Morton et al., 1991; Purcell et al., 1994). P. insidiosum is morphologically similar to other species of zygomycete fungi in the Mucoraceae or Entomophthoracea families such as Basidiobolus spp. and Conidiobolus spp. (Brown and Roberts, 1988), respectively; however, fungi in the Mucoraceae family tend to invade blood vessels of the gastrointestinal mucosa and submucosa, causing infarcts and hemorrhages (Barker et al., 1993), which were not seen in this case. On the other hand, the entomophthoromycosis caused by Conidiobolus spp. usually affect cranial parts of the digestive system such as lips and oropharynx (Barker et al., 1993).

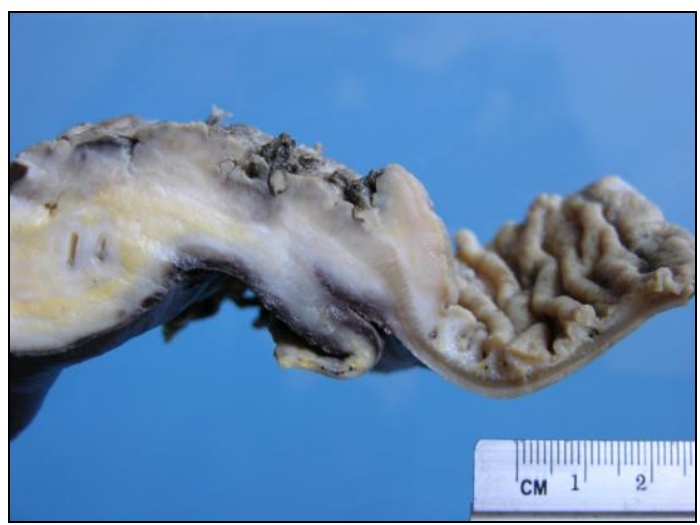

Figure 1. Formalin fixed jejunal segment showing thickened wall with ulcerative areas in the mucosa associated with white to yellow necrotic and pale fibrotic areas.

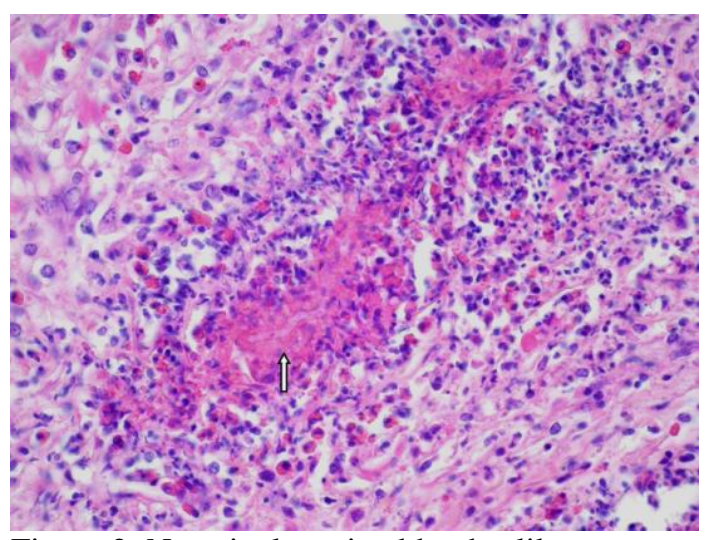

Figure 2. Negatively stained hyphaelike structure (arrow) in the middle of a focus of necrosis. Hematoxylin and eosin, 400x.

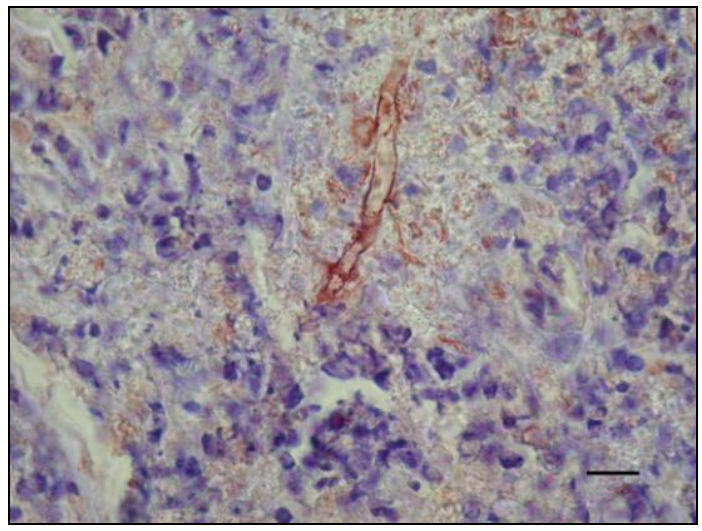

Figure 3. Immunohistochemistry using antibodies against $P$. insidiosum revealing strong positive immunostaining of the hyphaelike structure walls, 1000x. Bar $=50 \mu \mathrm{m}$.

The signs of colic reported here were probably associated with the partial luminal obstruction present in the jejunal segment. Similar cases of intestinal pythiosis have already been described in horses (Brown and Roberts, 1988; Morton et al., 1991; Purcell et al., 1994), also affecting the jejunum. Although the need of previous injury on the intestinal mucosa for penetration of $P$. insidiosum has been implicated as an important factor for infection (Morton et al., 1991; Purcell et al., 1994), the ability of active penetration by the agent has also been indicated (Brown and Roberts, 1988). The disease has been attributed to ingestion of $P$. insidiosum-contaminated water (Brown and Roberts, 1988) that may also have been the route of infection in this case.

Keywords: equine, intestinal pythiosis, immunohistochemistry, Pythium insidiosum 


\section{RESUMO}

Uma égua, Puro Sangue Inglês, de oito anos de idade, apresentou-se com um quadro de cólica e foi submetida ao procedimento de laparotomia exploratória, na qual foi realizada enterectomia de uma porção do jejuno devido à presença de estenose intestinal parcial. O segmento afetado apresentou espessamento de parede, focos de ulceração, necrose e fibrose. O exame microscópico revelou enterite piogranulomatosa, multifocal coalescente, transmural, com focos necróticos contendo imagens negativas de estruturas semelhantes a hifas. A coloração de Prata Metenamina de Grocott demonstrou numerosas hifas esparsamente septadas e irregularmente ramificadas que foram fortemente positivas para anticorpos contra Pythium insidiosum na imuno-histoquímica. O diagnóstico de pitiose intestinal baseou-se nos achados macro e microscópicos e na imuno-histoquímica.

Palavras-chave: equino, pitiose intestinal, imuno-histoquímica, Pythium insidiosum

\section{ACKNOWLEDGMENTS}

The authors gratefully acknowledge Dr. Cláudio Estevão Farias Cruz for revising the manuscript.

\section{REFERENCES}

BARKER, I.K.; VAN DREUMEL, A.A.; PALMER, N. The alimentary system. In: JUBB, K.V.F.; KENNEDY, P.C.; PALMER, N. (Eds). Pathology of domestic animals. San Diego: Academic, 1993. p.1-30.

BOSCO, S.M.G.; BAGAGLI, E.; ARAUJO JR, J.P. et al. Human Pythiosis, Brazil. Emerg. Infect. Dis., v.11, p.715-718, 2005.

BROWN, C.C.; ROBERTS, E.D. Intestinal pythiosis in a horse. Aust. Vet. J., v.65, p.88-89, 1988.

BROWN, C.C.; McCLURE, J.J.; TRICHE, P. et al. Use of immunohistochemical methods for diagnosis of equine pythiosis. Am. J. Vet. Res., v.49, p.1866-1868, 1988.

DYKSTRA, M.J.; SHARP, N.J.H.; OLYVRY, T. et al. A description of cutaneous-subcutaneous pythiosis in fifteen dogs. Med. Mycol., v.37, p.427-433, 1999.

MORTON, L.D.; MORTON, D.G.; BAKER, G.J. et al. Chronic eosinophilic enteritis attributed to Pythium sp. in a horse. Vet. Pathol., v.28, p.542-544, 1991.
PEDROSO, P.M.O.; BEZERRA JÚNIOR, P.S.; PESCADOR, C.A. et al. Diagnóstico imunohistoquímico de pitiose cutânea em equinos. Acta Sci. Vet., v.37, p.49-52, 2009.

PEREIRA, D.I.B.; SANTURIO, J.M.; ALVES, S.H. et al. Caspofungin in vitro and in vivo activity against Brazilian Pythium insidiosum strains isolated from animals. J. Antimicrob. Chem., v.60, p.1168-1171, 2007.

PURCELL, K.L.; JOHNSON, P.J.; KREEGER, J.M. et al. Jejunal obstruction caused by a Pythium insidiosum granuloma in a mare. J. Am. Vet. Med. Assoc., v.205, p.337-339, 1994.

SANTURIO, J.M.; MONTEIRO, A.B.; LEAL, A.T. et al. Cutaneous Pythiosis insidiosi in calves from the Pantanal region of Brazil. Mycopathologia, v.141, p.123-125, 1998.

SANTURIO, J.M.; ALVES, S.H.; PEREIRA, D.B. et al. Pitiose: uma micose emergente. Acta Sci. Vet., v.34, p.1-14, 2006.

TABOSA, I.M.; RIET-CORREA, F.; NOBRE, V.M.T. et al. Outbreaks of Pythiosis in two flocks of sheeps in Northeastern Brazil. Vet. Pathol., v.41, p.412-415, 2004. 